\title{
Мария Вятчина
}

\section{Stefania Pandolfo. Knot of the Soul: Madness, Psychoanalysis, Islam. Chicago: University of Chicago Press, 2018. 384 pp. ISBN 978-0-226-46492-3.}

\begin{abstract}
Мария Вятчина, Центр независимых социологических исследований*. Адрес для переписки: ЦНСИ, а/я 1993, Санкт-Петербург, 191040, Россия. maria.vyatchina@gmail.com.
\end{abstract}

Этнографическая работа Стефании Пандолфо может привлечь внимание читателей уже тем, что объединяет в заглавии два волнующих современников слова: психоанализ и ислам. Если интерес к первому во многом продиктован тем, как в социальных науках разворачивается эмоциональный поворот, то ислам по-прежнему ассоциируется с образом Другого и постколониальным наследием. Фразы из эпиграфа соответствуют первым ожиданиям: это следующие одна за другой цитаты Жака Лакана о болезни, манифестирующей существование субъекта; средневекового исламского богослова Аль-Газали о фикхе, объединяющем принципы исламского права; наконец, два отрывка из разговоров с участниками исследования - Имамом (здесь и далее с прописной буквы, потому что речь идет о конкретном персонаже) и анонимным пациентом, который спрашивает исследовательницу, знакомо ли ей безумие. С первых страниц эта книга одновременно завораживает, сбивает с толку и заставляет раз за разом возвращаться к приведенным трактовкам из широко обсуждаемых философских работ. Но обо всем по порядку.

Начав полевые исследования в Марокко в 1990-е, написав затем книгу с позиций постколониальной критики (Pandolfo 1997) и несколько статей о субъектности и исторической памяти, в 2018 году в издательстве Чикагского университета Пандолфо, наконец, выпускает вторую монографию - книгу, написанную по результатам своих многолетних исследований. Названия журналов, в которых уже опубликованы рецензии, сигнализируют о междисциплинарной области, в которую попадает эта книга, а также о большом интересе к работе и ее востребованности. «Political Theology», «Psychoanalysis and History», «Qui Parle: Critical Humanities and Social Sciences», «Modern Intellectual History», «European Journal of Psychotherapy \& Counselling», «Journal of Islamic Studies» входят в этот список названий, но ими он далеко не исчерпывается.

Поэтический язык исламского мистицизма становится в руках исследовательницы дополнительным инструментом, позволяющим погрузить читателя в описываемые реалии. В разделе с благодарностями Пандолфо применяет (с. 353) для описания проделанного труда понятие аманат (араб. amāna). В исламе аманатом принято называть нематериальную ценность, доверенную на хранение. Аманатом в этом большом проекте становятся личные истории собеседников, пережи-

По решению Минюста РФ, АНО «ЦНСИ» включена в реестр некоммерческих организаций, выполняющих функции иностранного агента (7-Ф3 «0 некоммерческих организациях»). 
тый опыт, разговоры с духовными наставниками. Кроме долгого и тщательного осмысления безумия в обществе с превалирующими религиозными ценностями, многолетний проект Пандолфо поражает масштабом - здесь множество историй, сюжетов и локаций: крупный госпиталь, городская квартира, сон, глоссолалия, сельская свадьба, левитация, отчуждение, гендерное и классовое неравенства, семинары для психотерапевтов. Уже от одного нагромождения объектов наблюдения немного кружится голова. Такую манеру, которую можно сопоставить со стратегией мультисайтной этнографии, сама исследовательница называет миниатюристской (с. 35). Каждый персонаж раскрывается в отведенной ему миниатюре, а между описаниями героев располагается интерлюдия с рефлексиями автора о посещении семинара по психоанализу.

Семнадцать глав книги складываются в три неравные части. Первая часть помещает читателей в институциональное пространство психиатрического госпиталя. Выстроенное еще при колониальной администрации, здание напоминает о том, что европейское изобретение психиатрии не может просто взять и покинуть стены, освященные именем Зигмунда Фрейда. В номенклатуре продолжают использоваться французские термины, в то время как медицинские специалисты проводят сеансы с пациентами (которые постепенно превращаются в наших знакомых) на местном варианте арабского и берберского языков. Осознать эти противоречия между видимым и наблюдаемым нам поможет другой видный психоаналитик XX века - Франц Фанон. Страница за страницей убеждают нас в том, что феномен безумия выходит далеко за пределы упорядоченных нозологических списков. Безумие не остается в вакууме: оно связано с беспокойством и тревожностью от драматических событий, происходящих теперь уже в постколониальном мире. Кампании против терроризма, война в Афганистане, Палестинская интифада словно эхом отражаются в этих стенах, отголоски всех этих событий слышатся в стонах больных, оказавшихся в приемном покое.

Приемный покой сменяется интерьером квартиры во второй части книги, здесь один из новых героев, Ильяс, страдающий от зрительных галлюцинаций, создает удивительные изображения. Эти картины становятся частью книги, они же приводят в текст Аби Варбурга и инициируют разговор, который продлится семь лет. Продолжительные и сложные сцены напоминают о том, что представленная книга - не просто аналитическое изложение, это ожидания и взаимности, чаяния и терапевтические разговоры десятков людей, связанных с исследователем. Вот почему «Узел души» - настолько непростой для рецензирования текст.

Еще девять лет исследований, как пишет Пандолфо, связаны с третьей частью книги, которую она называет самой длинной и самой неполной. Эта часть посвящена переводу размышлений о безумии на еще один важный язык - язык исламского права, в котором аналогом популярного термина self становится термин нафс. Вместе с главным собеседником Пандолфо, Имамом, и другим персонажем - возможно, одним из самых известных имамов, средневековым богословом имамом Аль-Газали - мы движемся к описаниям традиционного мусульманского метода целительства при помощи чтения Корана, известного также как рукийя (араб. ruqya). Новое распространение этой практики описывается как часть раз- 
вивающегося исламского возрождения. Колониальные администрации известны тем, что проводили политику облитерации, то есть уничтожения, индигенной медицины. Вместе с гигиенистскими кампаниями по борьбе с инфекционными заболеваниями в Северной Африке запрещали и искореняли существовавшие здесь целительские практики. Распространение рукийя можно рассматривать как «справедливое» возвращение того, что уничтожалось в колониальную эпоху. Но именно здесь таится одно из важных противоречий.

К концу книги появляется ощущение, что после долгого исследовательского пути с горизонта совсем исчезают вернакулярные практики и остается только религиозная доктрина. Как будто вслед за Имамом, который в одном из разговоров определяет распространенное среди местных жителей посещение могил святых как ширк, то есть следование язычеству (с. 267), исследовательница сама начинает разделять эту идею. При этом нельзя предполагать, что в поле совсем не встречались примеры вернакулярных практик. Например, мы можем найти их в истории сельской девушки Хинд (с. 92), в пациентской карточке которой содержалось упоминание об обращении к Гнауа (араб. Gnawa). В тексте есть небольшая ремарка о том, что пациентская карточка не давала никаких расшифровок этого понятия. Предполагается, что персонал клиники хорошо осведомлен и не нуждается в уточнениях. Однако в подобных уточнениях нуждаемся мы, читатели.

Мимоходом упомянутые Гнауа - большое мистическое объединение, транслокальность и масштабы которого хорошо показаны в документальном фильме бельгийского режиссера Дирка Дюмона «Жить с невидимками» (2003) ${ }^{1}$. Насыщенное аудиовизуальное повествование Дюмона ведет нас вслед за героями, ищущими исцеления от своих «странных» состояний, из бывших метрополий в марокканские святилища. В самом начале одна из героинь фильма признается, что ей повезло найти в европейском мегаполисе терапевта марокканского происхождения. Она убеждена: окажись принимающий врач бельгийцем, ее бы непременно отправили в психиатрическую клинику. Этот внешний по отношению к этнографии марокканский сюжет дает гораздо больше для понимания множественностей душевных состояний, нежели долгое путешествие вместе с Пандолфо. Упоминаемые в первой части книги локальные техники преодоления недугов - долгие терапевтические квесты с посещением могил святых, целителей, обсуждения способов избавления от сихра (араб. «колдовство») - в конце книги практически растворяются. Растеряв вернакулярные сюжеты, описываемые сакральные ландшафты оскудевают; в книге остаются как дихотомия только вестернизированная госпитальная модель и исламская теология. Сама Пандолфо определяет эту дихотомию как «два связанных, но очень разных места в Марокканской истории безумия: психиатрический госпиталь и реформистский мир мусульманского целительства» (с. 9). Почему из этой сложной картины изымается ось вернакулярности, остается до конца не понятным.

${ }^{1}$ Благодарю Ольгу Христофорову за рекомендацию и возможность посмотреть этот документальный фильм. 
Тенденцию к дуализации в поле осмысления душевных недомоганий обнаруживают и другие исследователи. Например, антрополог Ана Винеа, которая изучает ревитализацию исламского целительства в Египте, показывает, как в публичном пространстве остаются только два способа объяснения: либо психическое расстройство, либо одержимость джиннами (Vinea 2021). Соответственно, у двух способов атрибуции недомогания может быть исключительно два способа лечения: либо психиатрическая клиника, либо целительская терапия. Винеа демонстрирует, что даже в условиях такого монополизирующего усечения, репертуары, которые пытаются объяснить необъяснимые состояния, все равно множатся. В египетском контексте, например, появляется концепт вахм (араб. wahm) - новая идея о персональной иллюзии одержимости (Vinea 2018).

Оглядываясь на исследования мусульманских сообществ, которые предпринимаются на постсоветском пространстве, можно увидеть близкие точки напряжения. Часто собранные этнографами и антропологами полевые материалы предлагают объемные описания разнообразных вернакулярных практик. Однако далеко не всегда для них находятся теологические объяснения. Вместе с тем существующие разборы, например, археографических находок остаются в историческом прошлом, не обнаруживая связей с теми, кто пытается фиксировать существующие сегодня ритуалы.

Несмотря на вопросы, представленная работа Пандолфо кажется очень своевременной и инспирирующей для исследователей религиозности на постсоветском пространстве. Кажется, нам очень недостает рефлексии о том, как и почему якутский шаман Александр Габышев отправляется на принудительное лечение, а на региональном телевидении чеченских целителей вынуждают приносить извинения за терапевтические сеансы. И это - не далекий Магриб, а многообразие опытов совсем рядом, где джинны, нечеловеческие акторы (nonhumans) (Khan 2006), вполне может статься, говорят по-русски.

\section{СПИСОК ЛИТЕРАТУРЫ}

Khan, Naveeda. 2006. "Of Children and Jinn: An Inquiry into an Unexpected Friendship During Uncertain Times." Cultural Anthropology 21(2):234-264. https://doi.org/10.1525 /can.2006.21.2.234.

Pandolfo, Stefania. 1997. Impasse of the Angels: Scenes from a Moroccan Space of Memory. Chicago: University of Chicago Press.

Vinea, Ana. 2018. “An Emergent Affliction in Today's Egypt: Islamic Healing, the Psy Sciences, and What Lies In-Between." Medicine Anthropology Theory 5(1):50-77. https://doi.org/10.17157 /mat.5.1.518.

Vinea, Ana. 2021. “Diagnostic Dilemmas." Africa Is a Country, June 17. https://africasacountry .com/2021/06/diagnostic-dilemmas. 